\title{
Can direct gas-liquid chromatography of clinical samples detect specific organisms?
}

\author{
B WATT, PAMELA A GEDDES, OLGA A GREENAN, SUSAN K NAPIER, A MITCHELL \\ From the Central Microbiological Laboratories, Western General Hospital, Crewe Road, Edinburgh EH4 \\ $2 X U$
}

SUMMARY A total of 1929 samples was analysed by direct gas-liquid chromatography and the volatile fatty acid (VFA) patterns of the positive samples were compared with the results of culture. There was no correlation between any bacterial genus or species and the detailed VFA patterns although the presence of butyric or valeric acids, or both, was generally associated with the presence of anaerobes and that of acetic acid was generally associated with aerobic bacteria; however, the technique could not predict the nature of the subsequent bacterial isolate. There was also poor correlation between the VFA pattern in a given sample and the VFA pattern(s) of anaerobic bacteria subsequently isolated from that sample.

In an accompanying paper we outline our experience of direct gas-liquid chromatography of clinical specimens over a three-year period. ${ }^{1}$ In the present paper we compare the results of aerobic and anaerobic culture with the detailed VFA results and discuss the correlation between VFA patterns obtained on direct chromatography of clinical samples with the patterns obtained from anaerobic bacteria cultured from the samples.

\section{Material and methods}

These were as given in the paper that follows.' In addition, chromatography was performed on cultures of anaerobic bacteria grown up for $\mathbf{4 8}$ hours in proteose peptone yeast extract broth with added glucose. The relative concentrations were peptone $20 \mathrm{~g} / \mathrm{l}$; yeast extract (Difco) $10 \mathrm{~g} / \mathrm{l}$; glucose $2 \%$.

VOLATILE FATTY ACID STANDARD SOLUTIONS The following volatile fatty acids were prepared as stock solutions each of $100 \mathrm{mmol} / \mathrm{l}$ aqueous solution: acetic $(\mathrm{A})$; propionic $(\mathrm{P})$; isobutyric (i-B); butyric (B); isovaleric ( $\mathrm{i}-\mathrm{V})$; valeric $(\mathrm{V})$; isocaproic (i-C), and caproic (C). The stock solutions were stored at $4^{\circ} \mathrm{C}$ and then $1 \mathrm{ml}$ of each solution was taken, mixed together $(8 \mathrm{ml})$ and to this was added 2 $\mathrm{ml}$ distilled water to give a reference solution containing $10 \mathrm{mmol} / \mathrm{l}$ of each of the test acids.

Accepted for publication 9 December 1981
The peak heights from the test sample or culture were compared with the appropriate reference acid and the concentrations of VFAs in the test sample or culture were assessed semiquantitatively by comparison with those of the reference solution. VFA concentrations were expressed as follows:

$A=$ acetic acid concentration $10 \%$ or more of standard solution.

(A) = acetic acid concentration $2-10 \%$ of standard solution.

Concentrations of a given VFA of less than $2 \%$ of the standard solution were ignored.

\section{Results}

A total of 1929 samples were processed. The principal VFA patterns obtained in samples yielding aerobic growth were acetic acid alone (139 sam-

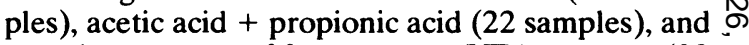
complex patterns of four or more VFA patterns (22 N samples). Many of these samples yielded a mixture ్్ of aerobic species; the results of culture from species 0 yielding a single aerobic species are compared with above VFA patterns in Table 1. From this, it is clear that acetic acid is found in samples that subsequently $\stackrel{\mathcal{\infty}}{?}$ yield a variety of aerobic organisms. Similarly, the 0 presence of acetic and propionic acids or of more $\overline{0}$ complex acids is not associated with the presence of $\mathbb{D}$ any one aerobic bacterial species. Indeed, the results $\mathbb{D}$ from 119 samples yielding a pure growth of Staphylococcus aureus show that $\mathbf{3 9}$ yielded acetic acid; 2 acetic and propionic acids; 1 acetic and 
Table 1 Correlation between principal VFA patterns and results of aerobic culture in samples yielding aerobes only*

\begin{tabular}{|c|c|c|c|c|c|c|}
\hline \multirow[t]{2}{*}{ VFA pattern $\dagger$} & \multicolumn{6}{|c|}{ Aerobic organisms isolated } \\
\hline & Staph aureus & Staph albus & $E$ coli & Streptococci & $\begin{array}{l}\text { Other } \\
\text { enterobacteria }\end{array}$ & Yeasts \\
\hline $\begin{array}{l}A \\
\text { A, P } \\
\geqslant 4 \text { VFAs }\end{array}$ & $\begin{array}{r}39 \\
2 \\
3\end{array}$ & $\frac{6}{2}$ & $\begin{array}{r}26 \\
5 \\
-\end{array}$ & $\begin{array}{l}5 \\
3 \\
2\end{array}$ & $\begin{array}{r}15 \\
9\end{array}$ & 2 \\
\hline
\end{tabular}

*Only samples yielding a single aerobic species.

$+\mathrm{A}=$ acetic acid; $\mathrm{P}=$ propionic acid.

Table 2 Correlation between VFA patterns and results of anaerobic culture in samples yielding anaerobic bacteria only*

\begin{tabular}{|c|c|c|c|c|c|c|}
\hline \multirow[t]{2}{*}{$V F A$ pattern $\dagger$} & \multicolumn{6}{|c|}{$\begin{array}{l}\text { No of anaerobic organisms showing } \\
\text { VFA pattern }\end{array}$} \\
\hline & $A C \ddagger$ & $C P$ & $O C$ & $B F$ & $O B$ & $F B$ \\
\hline A & 4 & 2 & 1 & 2 & - & 1 \\
\hline$A, P$ & 1 & 1 & - & 2 & - & - \\
\hline$A, i-B$ & - & - & - & 1 & - & - \\
\hline A, B & 3 & 1 & 2 & - & 1 & - \\
\hline$A, i-V$ & - & - & - & 1 & - & - \\
\hline A, P, i-B & - & - & - & 1 & - & - \\
\hline A, P, B. & 2 & - & - & 1 & - & - \\
\hline A, i-B, i-V & - & - & - & 2 & 2 & - \\
\hline A, i-B, V . & - & - & - & 1 & - & - \\
\hline A, P, i-B, i-V & - & - & - & 1 & - & - \\
\hline A, i-B, B, i-V & 2 & - & 1 & - & - & - \\
\hline A, P, i-B, B, i-V & - & 1 & - & 3 & 1 & - \\
\hline$A, P, i-B, B, i-C$ & 1 & - & - & - & - & - \\
\hline$A, P, i-B, B, i-V, i-C$ & 2 & - & 1 & - & - & - \\
\hline$A, P, i-B, B, i-V, V, C$ & - & 1 & - & - & - & - \\
\hline$A, P, i-B, B, i-V, V, i-C, C$ & & - & - & 1 & & \\
\hline
\end{tabular}

${ }^{*}$ Results shown are for samples yielding a single species of anaerobe on culture.

$+\mathbf{A}=$ acetic acid; $\mathbf{P}=$ propionic acid; $\mathrm{i}-\mathrm{B}=$ isobutyric acid; $\mathrm{B}=$ butyric acid; $\mathrm{i}-\mathrm{V}=$ isovaleric acid; $\mathrm{V}=$ valeric acid; $\mathrm{i}-\mathrm{C}=$ isocaproic acid; $\mathrm{C}=$ caproic acid.

$\ddagger \mathrm{AC}=$ anaerobic cocci; $\mathrm{CP}=$ Clostridium perfringens $; \mathrm{OC}=$ other clostridia; $\mathrm{BF}=$ Bacteroides fragilis $; \mathrm{OB}=$ other Bacteroides $\mathrm{spp}$; FB $=$ Fusobacterium sp.

butyric acids; 12 acetic and isovaleric acids; 1 acetic, isobutyric and isovaleric acids; and 3 samples yielded four or more VFAs. However by far the largest proportion of the total (61) samples showed no detectable VFAs on direct gas-liquid chromatography.

In the case of anaerobic bacteria there was a similar pattern; although most samples showing anaerobic growth yielded butyric or valeric acids, or both, often in combination with other VFAs, there was no clear correlation between these patterns and the type of anaerobic bacteria subsequently isolated from the samples. This was true both for samples yielding a pure growth of a single anaerobic species (Table 2) and for samples yielding a mixture of anaerobes or of aerobes and anaerobes.

This lack of correlation was further confirmed when we compared the VFA patterns of a given sample with the VFA patterns of the anaerobic bacteria subsequently isolated from that sample. The results of 10 representative samples (Table 3 ) show that although in a few samples there is some correlation, this does not hold for the majority of samples. For example, the results show that three samples yielded a mixture of acetic and butyric acids, that different organisms were isolated from each and that in each case a more complex VFA pattern was produced by the isolates than the simple acetic and butyric acids present in the sample. The only correlation that did emerge was that in general, samples yielding a mixture of VFAs that included isocaproic acid yielded a flora that included anaerobic cocci that were subsequently identified as Peptostreptococcus anaerobius. Cultures of this organism

Table 3 Correlation between VFA patterns from samples and VFA patterns from anaerobic isolates from the samples

\begin{tabular}{|c|c|c|c|c|c|}
\hline \multicolumn{2}{|c|}{ Sample No VFA pattern } & \multirow{2}{*}{$\begin{array}{l}\text { Anaerobic isolate(s) } \\
B \text { fragilis } \\
B \text { vulgatus } \\
C \text { paraputrificum }\end{array}$} & \multirow{2}{*}{ 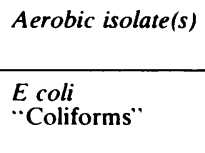 } & \multirow{2}{*}{$\begin{array}{l}\begin{array}{l}\text { VFA patterns of } \\
\text { anaerobic isolates }\end{array} \\
\mathrm{A}, \mathrm{P}, \mathrm{i}-\mathrm{B}, \mathrm{B}, \mathrm{i}-\mathrm{V} \\
\mathrm{A}, \mathrm{P}, \mathrm{i}-\mathrm{B}, \mathrm{i}-\mathrm{V} \\
\mathrm{A}, \mathrm{B}\end{array}$} & \multirow{2}{*}{$\begin{array}{l}\text { Nature of sample } \\
\begin{array}{l}\text { Pus } \\
\text { Wound exudate }\end{array}\end{array}$} \\
\hline $\begin{array}{l}645 \\
593\end{array}$ & $\begin{array}{l}\mathbf{A}^{*}, \mathbf{P} \\
\mathbf{A}, \mathbf{B}\end{array}$ & & & & \\
\hline $\begin{array}{l}969 \\
605 \\
989 \\
671 \\
606 \\
166 \\
425 \\
422\end{array}$ & $\begin{array}{l}\text { A } \\
\text { A, i-B, B, i-V, V, i-C } \\
\text { A } \\
\text { A, B } \\
\text { A, i-B, i-V } \\
\text { A, B } \\
\text { A, P, i-B, B, i-V } \\
\text { A, P, i-B, B, i-V }\end{array}$ & $\begin{array}{l}\text { Fusobacterium spp } \\
\text { Pst anaerobius } \\
\text { Anaerobic cocci } \\
C \text { perfringens } \\
B \text { fragilis } \\
\text { Anaerobic cocci } \\
C \text { chauvoei } \\
B \text { thetaiotaomicron }\end{array}$ & $\begin{array}{l}\bar{E} \text { coli } \\
\overline{\text { Staph albus }} \\
\text { E coli } \\
\text { Staph albus } \\
\text { E coli } \\
\text { E coli }\end{array}$ & $\begin{array}{l}\text { A, P, B } \\
\text { A, i-B, b, i-V }(V)+i-C \\
\text { A, P, B(i-B) } \\
\text { A, P, (i-B), B } \\
\text { A, P, i-B, B, i-V } \\
\text { A, P, B } \\
\text { A, B } \\
\text { A, P, i-B(B) i-V }\end{array}$ & $\begin{array}{l}\text { Wound exudate } \\
\text { Pus } \\
\text { Joint aspirate } \\
\text { Pus } \\
\text { Pus } \\
\text { Pus } \\
\text { Drain fluid } \\
\text { Pus }\end{array}$ \\
\hline
\end{tabular}

${ }^{*} \mathrm{~A}=$ acetic acid; $\mathrm{P}=$ propionic acid; $\mathrm{i}-\mathrm{B}=$ isobutyric acid; $\mathrm{B}=$ butyric acid; $\mathrm{i}-\mathrm{V}=$ isovaleric acid; $\mathrm{V}=$ valeric acid; $\mathrm{i}-\mathrm{C}=$ isocaproic acid; $\mathrm{C}=$ caproic acid.

$\dagger(\mathrm{V}),(\mathrm{i}-\mathrm{B})=$ concentrations of valeric and isobutyric acids respectively that are $2-10 \%$ of the relevant standard (see Material and methods). 
yielded a complex VFA pattern that included isocaproic acid.

\section{Discussion}

In an accompanying paper we report on the results of a three-year experience of direct gas-liquid chromatography in the diagnosis of anaerobic infections. ${ }^{1}$ It was clear that the technique was of use in the rapid presumptive diagnosis of anaerobic infections, with few "false-positives" or "false-negatives". We had hoped that analysis of the VFA patterns produced in a given sample would enable the anaerobic bacteria in that sample to be presumptively identified without having to wait for the results of culture and identification. This has not proved to be the case; with the exception of Pst anaerobius, there is no correlation between the VFA patterns produced and the species (or even genus) of anaerobic bacteria present in the sample. This is true both for samples with a pure anaerobic flora or mixed aerobic and anaerobic flora. Certainly it is not possible to predict whether or not an organism such as Bacteroides fragilis is present in a sample from analysis of the VFA patterns-this confirms the finding of Ladas and his co-workers. ${ }^{2}$ The reasons for this lack of correlation are not clear, although similar findings have been recorded by Nord. ${ }^{3}$ It may be that certain VFAs are not produced by anaerobic bacteria in vivo or that, although produced, they are bound in some way in the tissues and are not detectable by our methods.

Some workers, ${ }^{4}$ have used direct gas-liquid - chromatography to detect high concentrations of lactic acid in joint fluids as a non-specific indicator of bacterial infection, similar to the use of lactic acid levels in the differential diagnosis of meningitis. $^{5}$ We have found that gas-liquid chromatography is of little use in the presumptive diagnosis of aerobic infections, except that the presence of acetic acid only in a sample suggests that aerobic bacteria may be present in the sample but gives no indication as to the type of bacteria. We had hoped that organisms such as Staph aureus would be associated with a characteristic VFA pattern; this would have been of considerable assistance in, for example, suspected joint infections in which early and appropriate therapy is imperative. However, the results do not show any such correlation, indeed a majority of samples subsequently yielding Staph aureus show no VFAs.

There is no doubt that direct gas-liquid chromatography is a useful technique that can give a prompt presumptive diagnosis to clinical colleagues, ${ }^{6-9}$ and that it can in some situations, distinguish aerobic from anaerobic infections, as has been claimed by other workers. ${ }^{8}$ It can indeed answer the question: "Are anaerobes present in this sample?"-it cannot answer the question: "Which anaerobes are present?"

This research programme has been supported by a grant from the Scottish Hospital Endowments Research Trust. We thank Mrs EJ Boyle for secretarial assistance.

\section{References}

' Watt B, Geddes PA, Greenan OA, Napier SK, Mitchell A. Gas-liquid chromatography in the diagnosis of anaerobic infections: a three-year experience. $J$ Clin Pathol 1982;35:709-14.

${ }^{2}$ Ladas S, Arapakis G, Malamou-Ladas H, Palikaris G, Arseni A. Rapid diagnosis of anaerobic infections by gas-liquid chromatography. J Clin Pathol 1979;32:1163-7.

${ }^{3}$ Nord CE. Diagnosis of anaerobic infections by gas-liquid chromatography. Acta Pathol Microbiol Scand $[B]$ 1977;259:55-9.

${ }^{4}$ Seifert MH, Mathews JA, Phillips I, Gargan RA. Gas-liquid chromatography in the diagnosis of pyogenic arthritis. $\mathrm{Br}$ Med J 1978; ii: 1402 .

${ }^{5}$ Ferguson IR, Tearle PV. Gas-liquid chromatography in the rapid diagnosis of meningitis. J Clin Pathol 1978;30:1163-7.

- Anonymous. Gas chromatographic diagnosis of infection. Lancet 1980;vi:513-4.

' Phillips I, Taylor E, Eykyn S. The rapid laboratory diagnosis of anaerobic infection. Infection 1980;8, suppl 2:155-9.

${ }^{8}$ Reig M, Milina D, Loze E, Ledesma MA, Messeguer MA. Gasliquid chromatography in routine processing of blood cultures for detecting anaerobic bacteraemia. J Clin Pathol $1981 ; 34: 189-93$.

- Tabacqchali S, Fiddian AP, Atkinson P. Recent techniques in the investigation and diagnosis of anaerobic infections. $J$ Infect 1979;1, suppl 1:13-24.

Requests for reprints to: Dr B Watt, Central Microbiological Laboratories, Western General Hospital, Crewe Road, Edinburgh EH4 2XU, Scotland. 